\title{
PERANAN BAGIAN ADMINISTRASI KANTOR PT TANGARA MITRAKOM JAKARTA PUSAT
}

\author{
Edi Junaedi \\ Dosen Prodi D-III Sekretari Universitas Pamulang \\ email : edijun6976@gmail.com
}

\begin{abstract}
ABSTRAK
Sumber Daya Manusia yang bekerja di perusahaan atau karyawan adalah salah satu unsur yang memiliki peranan strategis dalam menyelenggarakan tugas-tugas umum perkantoran. Untuk mewujudkan tuntutan tersebut diperlukan adanya karyawan yang memiliki kompetensi tinggi. Karyawan yang mengemban pelimpahan wewenang untuk membantu tugas dari pimpinan dalam melaksanakan pekerjaan kantor adalah seorang staf administrasi, yang berperan penting dalam menjaga kelangsungan hidup sebuah organisasi, dikerenakan pekerjaan pimpinan tidak akan berjalan dengan lancar dan baik tanpa bantuan seorang tenaga administrasi. Laporan yang diberikan oleh staf administrasi untuk atasan tidak bertentangan dengan aturan perundang-undangan yang berlaku, dimana semua laporan dapat dipertanggungjawabkan, hal ini menyangkut sumber yang didapatkan, serta proses yang dilakukan dan juga hasil yang dapatkan. Dengan adanya staf administrasi kantor pekerjaan akan lebih rapi dan teratur sesuai dengan tugas yang diperintahkan, sistem pencatatan dan dokumentasi tersimpan dengan baik dan apabila dibutuhkan akan mudah untuk dicari, perusahaan juga dapat dengan mudah mengikuti segala perkembangan perusahaan melalui laporan hasil pencatatan dan dokumentasi yang dicatat oleh staf administrasi.
\end{abstract}

Kata kunci :Karyawan, Administrasi, Wewenang, Organisasi

\section{PENDAHULUAN}

\section{Latar Belakang Masalah}

Karyawan adalah salah satu unsur yang memiliki peranan strategis dalam menyelenggarakan tugas-tugas umum perkantoran. Untuk mewujudkan tuntutan tersebut diperlukan adanya karyawan yang berkualitas. Karyawan yang berkualitas adalah karyawan yang memiliki kecakapan dan kemampuan untuk melaksanakan setiap tugas yang dibebankan kepadanya dengan baik, serta mampu memelihara dan mengembangkan kecakapan dan kemampuan yang dimilikinya secara berkesinambungan. Dengan semakin berkembangnya organisasi sebagaimana yang harus dilakukan oleh seorang pimpinan apabila seorang administrasi tersebut benar-benar telah memiliki kepercayaan penuh dari pimpinan untuk 
pengambilan keputusan tingkat awal dapat dilakukan oleh seorang staf administrasi dengan pertimbangan-pertimbangan yang rasional.

Dalam hal ini, karyawan yang mengemban pelimpahan wewenang untuk membantu tugas dari pimpinan dalam melaksanakan pekerjaan kantor ialah seorang staf administrasi, yang berperan penting dalam menjaga kelangsungan hidup sebuah organisasi, dikerenakan pekerjaan pimpinan tidak akan berjalan dengan lancar dan baik tanpa bantuan seorang staf administrasi. Administrasi merupakan suatu hal yang sangat vital bagi perusahaan karena untuk mengukur baik atau tidaknya suatu perusahaan salah satunya dapat dilihat melalui administrasi. Bila administrasi kurang mendapatkan perhatian akan mengakibatkan kerugian pada perusahaan, salah satu kerugiannya adalah memperlambat proses pemberian informasi yang diperlukan. Dunia administrasi sebagai suatu profesi telah jauh berkembang sedemikian rupa sehingga berkembang pula menjadi suatu profesi yang sangat penting dan selalu diperlukan oleh setiap perusahaan, baik dalam ruang lingkup yang masih sederhana sampai kepada ruang lingkup industri besar.

Sejalan dengan semakin berkembangnya organisasi sebagaimana yang harus dilakukan oleh seorang pimpinan apabila seorang administrasi tersebut benar-benar telah memiliki kepercayaan penuh dari pimpinan untuk pengambilan keputusan tingkat awal dapat dilakukan oleh seorang administrasi dengan pertimbangan-pertimbangan yang rasional. Sehingga seorang administrasi yang profesional harus dapat memaknai tugas dan tanggung jawab secara menyeluruh, administrasi dapat dikatakan pula sebagai pengganti atau tangan kanan ketika pimpinan sedang tidak berada dilingkungan kerja.

Selain itu laporan yang diberikan oleh administrasi untuk atasan atau perusahaan tidak bertentangan dengan perundang-undangan yang berlaku dimana semua laporan dapat dipertanggungjawabkan, hal ini menyangkut sumber yang didapatkan, serta proses yang dilakukan dan juga hasil yang didapatkan. Agar dapat mengukur, mengungkapkan, serta upaya perusahaan untuk menjadi sebuah perusahaan yang dapat dipertanggungjawabkan sesuai dengan peraturan dan perundang-undangan yang berlaku. Hal ini pula yang terjadi di PT Tangara Mitrakom Jakarta Pusat, pekerjaan seorang staf administrasi divisi operation sangat berkaitan dengan kelancaran kegiatan kerja di PT Tangara Mitrakom Jakarta Pusat dan dari kinerja seorang staf administrasi yang cakap dia mampu mengatur, mengelola, dan menata pembukuan beserta laporan-laporan yang dibutuhkan oleh pimpinan. 


\section{Identifikasi Masalah}

Berdasarkan latar belakang dalam peranan administrasi kantor yang ada, maka penulis membuat identifikasi masalah sebagai berikut:

1. Peranan Bagian Administrasi Kantor di PT Tangara Mitrakom Jakarta Pusat.

2. Hambatan yang dialami saat melakukan pekerjaan administrasi Kantor di PT Tangara Mitrakom Jakarta Pusat.

3. Manfaat yang didapatkan dengan adanya Bagian Administrasi Kantor di PT Tangara Mitrakom Jakarta Pusat.

\section{Pembatasan Masalah}

Berdasarkan identifikasi masalah di atas dan karena keterbatasan waktu yang dimiliki oleh penulis serta untuk menghindari terlalu luasnya masalah, maka penulis membatasi bahasan dengan judul yang disesuaikan dengan kepentingan yang penulis anggap dapat mencakup keseluruhan materi, yaitu permasalahan mengenai "Peranan Bagian Administrasi Kantor PT Tangara Mitrakom Jakarta Pusat”.

\section{Rumusan Masalah}

Untuk mengetahui sejauh mana Peranan Administrasi Kantor di PT Tangara Mitrakom Jakarta Pusat, Maka penulis dapat membuat rumusan masalah sebagai berikut:

1. Apa saja peranan Bagian Administrasi kantor di PT Tangara Mitrakom Jakarta Pusat?

2. Bagaimana cara mengatasi hambatan-hambatan yang sering terjadi pada Bagian Administrasi kantor di PT Tangara Mitrakom Jakarta Pusat?

3. Apa manfaat yang didapatkan dengan adanya peranan Bagian Administrasi kantor di PT Tangara Mitrakom Jakarta Pusat?

\section{Metode Penulisan}

Penulis melakukan beberapa metode dalam proses penulisan dan pengumpulan data, melalui cara sebagai berikut lain :

1. Metode Observasi 
Proses pengamatan objek penulisan secara langsung di lapangan pada saat melakukan observasi. Penulisan melakukan pengamatan langsung ke PT Tangara Mitrakom tersebut untuk segala sesuatu yang ada kaitannya dengan Peranan Staf Administrasi Kantor Di PT Tangara Mitrakom Jakarta Pusat.

2. Metode Kepustakaan

Penulis mencari data dan fakta dengan mengkaji sumber-sumber pustaka yang berhubungan dengan objek penulisan. Dalam hal ini penulis memperoleh data dari buku-buku yang dapat menyempurnakan penulisan ini.

\section{LANDASAN TEORI}

\section{Pengertian Administrasi}

Para ahli membuat pengertian atau mendifinisikan kata administrasi dengan kalimat yang berbeda-beda, akan tetapi apabila kita tinjau dari asal usul katanya (Etimologi) maka administrasi berasal dari Bahasa latin yang terdiri dari dua kata yaitu ad dan ministrare, kata ad diartikan ke atau kepada, dan ministrare diartikan melayani atau mengarahkan.

Administrasi dapat dibedakan menjadi 2 (dua) pengertian, yaitu administrasi dalam arti sempit dan administrasi dalam arti luas:

1. Administrasi dalam Arti Sempit

Administrasi dalam arti sempit adalah kegiatan penyusunan dan pencatatan data dan informasi secara sistematis dengan tujuan untuk menyediakan keterangan serta memudahkan untuk memperolehnya kembali secara keseluruhan dalam satu hubungan atau satu sama lain.

2. Administrasi dalam Arti Luas

Administrasi dalam arti luas adalah kegiatan kerja sama yang dilakukan sekelompok orang berdasarkan pembagian kerja sebagaimana ditentukan dalam struktur dengan mempergunakan sumber daya untuk mencapai tujuan secara efektif dan efisien. Jadi pengertian administrasi dalam arti luas memiliki unsur-unsur sekelompok orang, kerjasama, pembagian tugas secara terstruktur, kegiatan yang bertahap dalam proses, tujuan yang akan dicapai, dan pemanfaatan sebagai sumber. 


\section{Menurut kamus besar bahasa Indonesia, administrasi adalah:}

1. Usaha dan kegiatan yang meliputi penetapan tujuan serta penetapan cara-cara penyelenggaraan pembinaan organisasi.

2. Usaha dan kegiatan yang berkaitan dengan penyelenggaraan kebijakan untuk mencapai tujuan.

3. Kegiatan yang berkaitan dengan penyelenggaraan pemerintahan.

4. Administrasi merupakan pekerjaan kertas (paper work), atau pekerjaan tulis-menulis.

5. Pencatatan dan pemberian bahan-bahan Kegiatan kantor dan tata usaha yang diperlukan untuk pelaksanaan kegiatan pimpinan.

\section{Pengertian administrasi dikemukakan oleh beberapa ahli diantaranya adalah :}

1. Prof. Dr. Sondang P. Siagian, MPA.

Administrasi adalah keseluruhan proses kerjasama antara dua orang atau lebih yang berdasarkan atas rasional tertentu untuk mencapai tujuan yang telat ditentukan sebelumnya.

2. H. A. Simon

Administrasi adalah sebagai aktivitas-aktivitas kelompok yang bekerja sama untuk mencapai tujuan.

3. Drs. The Liang Gie

Administrasi adalah segenap rangkaian perbuatan penyelenggaraan dalam setiap usaha kerjasama sekelompok manusia untuk mencapai tujuan tertentu.

4. Van der Schroeff

Administrasi merupakan seluruh himpunan catatan-catatan mengenai perusahaan dan peristiwa-peristiwa perusahaan untuk keperluan pimpinan dan penyelenggaraan perusahaan.

5. William H. Newman

Administrasi adalah bimbingan, kepemimpinan dan pengawasan terhadap usaha kelompok atau individu agar tercapainya sebuah tujuan.

Pada dasarnya administrasi merupakan rangkaian aktivitas merencanakan, mengorganisasi (mengatur dan menyusun), mengarahkan (memberikan arah dan petunjuk), mengawasi dan mengendalikan (melakukan kontrol) sampai menyelenggarakan secara tertib 
sesuai tujuan mengenai sesuatu hal atau kegiatan. Hal atau sasaran yang terkena oleh rangkaian kegiatan itu pada umumnya ialah pekerjaan perkantoran (office work). Intinya, administrasi melingkupi seluruh kegiatan, dari pengaturan hingga pengurusan sekelompok orang yang memiliki diferensiasi pekerjaan untuk mencapai suatu tujuan bersama. Administrasi dapat berjalan dengan dua atau banyak orang terlibat di dalamnya.

Administrasi kantor dapat dijalankan dengan sistem sentralisasi, desentralisasi, atau gabungan dari keduanya. Dengan sistem sentralisasi pekerjaan kantor dijalankan oleh satu kantor pusat atau unit tertentu saja. Bila organisasi mencangkup banyak bidang atau bagian, maka diperlukan desentralisasi, dimana sebagian pekerjaan kantor dilaksanakan oleh unit administrasi dari masing-masing bagian.

Pada banyak organisasi, prinsip sentralisasi dan desentralisasi kerap digabungkan. Hal-hal administratif yang khusus berkaitan langsung dengan pekerjaan unit tertentu dikerjakan oleh bagian administrasi unit yang bersangkutan, sementara hal-hal yang umum ditangani oleh sebuah kantor pusat. Karena yang terpenting adalah pekerjaan kantor perlu dikelola seefektif dan seefisien mungkin sehingga dalam menjalankan administrasi tidak terjadi hal yang dapat merugikan karyawan dan perusahaan.

\section{Maksud dan Tujuan Administrasi}

Pencatatan semua kegiatan usaha yang sangat diperlukan bagi kelancaran dan pengelolaan perusahaan merupakan tugas administrasi. Tugas-tugas administrasi sendiri meliputi pencatatan data-data transaksi bisnis, pencatatan data-data keuangan, pencatatan datadata produksi, pencatatan data-data persediaan produksi, pencatatan data-data kegiatan yang diadakan oleh perusahaan baik dilingkungan kantor maupun diluar lingkungan kantor dan pencatatan data lain yang dapat mempengaruhi kelancaran perusahaan.

Adapun maksud dan tujuan adanya administrasi adalah agar dapat :

1. Memantau kegiatan-kegiatan administrasi perusahaan

2. Mengevaluasi kegiatan-kegiatan perorganisasian perusahaan

3. Menyusun program pengembangan usaha dan kegiatan perorganisasian perusahaan

4. Mengamankan kegiatan-kegiatan usaha dan organisasi perusahaan

\section{Manfaat Administrasi}


Manfaat dari administrasi Kantor adalah sebagai berikut:

1. Perusahaan akan dapat dengan mudah menghubungi pihak-pihak lain melalui berbagai media komunikasi baik itu rekanan kerja maupun instansi pemerintah.

2. Resiko perbedaan pencatatan dokumentasi akan dapat diperkecil karena setiap transaksi akan dibukukan dan dicatat dengan rapi.

3. Memudahkan seseorang apabila mencari dan menunjukkan bukti-bukti pencatatan dokumentasi.

4. Pemilik perusahaan dapat dengan mudah mengikuti perkembangan perusahaannya melalui laporan hasil pencatatan.

\section{Fungsi Administrasi}

Administrasi mempunyai berbagai fungsi diantaranya adalah:

1. Perencanaan

Administrasi selalu diawali dengan perencanaan, dalam perencanaan ini administrator berkegiatan untuk merumuskan, memilih dan menetapkan apa saja yang menjadi aktivitas-aktivitas sumber daya yang akan dilaksanakan dan mungkin yang akan digunakan untuk mencapai suatu tujuan. Jadi perencanaan adalah sebuah penuntun yang disusun sedemikian rupa yang sulit untuk dirubah, sedangkan definisi perencanaan adalah sebagai suatu proses mempersiapkan alternatif keputusan bagi kegiatan masa depan yang diarahkan kepada pencapaian tujuan dengan usaha yang optimal mempertimbangkan kenyataan-kenyataan yang ada dibidang ekonomi, sosial dan budaya secara menyeluruh dari suatu negara.

2. Organisasi

Pengorganisasian merupakan kegiatan dimana aktivitasnya berisi tentang menyusun dan membentuk hubungan kerja antar pribadi ataupun kelompok, sehingga terwujud suatu kesatuan usaha dalam menempuh tujuan yang sudah ditetapkan oleh perusahaan. Terdapat empat aspek atau syarat yang harus dipertimbangkan dalam organisasi yaitu:

a. Legitimasi

Legitimasi yaitu perusahaan mampu memberikan performansi organisasi yang dapat meyakinkan pihak-pihak terkait akan kemampuan untuk mencapai tujuan.

b. Efisiensi 
Efisiensi yaitu kejujuran atau keterbukaan terhadap perusahaan mengenai penggunaan waktu, penggunaan uang atau petty cash, serta penggunaan barangbarang milik perusahaan.

c. Keefektifan

Keefektifan yaitu menggambarkan ketepatan dalam pembagian tugas, pembagian tanggung jawab, menjalin hubungan kerja dengan perusahaan lain, penempatan bagian-bagian organisasi hingga menentukan karyawan yang melaksanakan tugas tersebut.

d. Keunggulan

Keunggulan disini menggambarkan kemampuan organisasi dari pimpinan hingga bawahan dalam melaksanakan fungsi dan tugasnya sehingga dapat meningkatkan kualitas diri sendiri, kualitas tim atau kelompok, kualitas perusahaan.

3. Kepegawaian

Kepegawaian adalah pengisian suatu bidang unit dengan personal yang akan melaksanakan tugas kegiatannya. Dalam kepegawaian yang menjadi kunci utamanya ialah personel itu sendiri. Aktifitas yang dilakukan dalam kepegawaian antara lain: menentukan, memilih, menempatkan dan membimbing karyawan atau personel yang berada di perusahaan.

4. Pengarahan

Pengarahan ialah sebagai penjelasan, petunjuk, pertimbangan dan bimbingan terhadap para karyawan atau personel yang terlibat, baik secara struktural maupun fungsional agar pelaksanaan tugas dapat berjalan dengan baik dan lancar. Pengarahan yang diberikan perusahaan kepada karyawan atau personel menjadikan mereka dalam bekerja lebih efektif, berpengetahuan luas dan dapat mencapai tujuan yang sudah ditetapkan oleh perusahaan. Adapun fungsi pengarahan ini adalah suatu cara berfikir dalam perusahaan yang meliputi pengamatan, pengertian terhadap konsep dan keyakinan untuk mengambil tindakan, oleh karena itu dalam sebuah tim, atau kelompok di perusahaan penting adanya kerjasama namun tidak terlepas pada pemantauan dari perusahaan itu sendiri

\section{Koordinasi}

Kordinasi pada umumnya tidak efektif karena sering muncul sistem birokrasi, ini akan terjadi jika organisasi menajdi terlalu besar dan rumit untuk dikelola. Akan tetapi 
koordinasi menurut The Liang Gie (1983:216) merupakan rangkaian aktifitas yang menghubungkan dan menyelaraskan orang-orang dan pekerja. Sedangkan Oteng Sutisna (1983:199) merumuskan koordinasi ialah menyatukan sumbangan ide atau pendapat dari orang-orang maupun sumber lainnya yang mengarah pada tercapainya maksud dan tujuan yang telah ditetapkan oleh perusahaan.

6. Anggaran

Anggaran sebagai aspek penting dalam kebutuhan sehari-hari, kegiatan yang berisi tentang dana dan anggaran disebut pembiayaan, dalam perusahaan pembiayaan ini adalah kegiatan mendapatkan biaya serta mengelola untuk kebutuhan kegiatan yang akan dilaksanakan oleh perusahaan.

7. Pergerakan

Pergerakan merupakan aktifitas seorang pimpinan dalam memberi perintah, memberi tugas, memberi arahan serta menuntun karyawan atau personel untuk melaksanakan pekerjaan-pekerjaan dalam mencapai tujuan yang telah ditentukan oleh perusahaan. Bawahan harus melakukan pergerakan dengan sebaik-baiknya apabila atasannya menaruh kepercayaan padanya.

8. Pengawasan

Kegiatan pengawasan dilakukan untuk penyesuaian terhadap rencana atau tujuan yang sudah ditentukan oleh perusahaan dan mengusahakan agar tidak terjadinya penyimpangan dalam sebuah perusahaan, dengan demikian dapat ditegaskan bahwa sasaran pengawasan adalah perilaku individu sebagai orang yang memproses lancarnya kegiatan pembelajaran dan tidak terjadinya penyimpangan.

9. Penilaian

Penilaian adalah aktivitas untuk meneliti dan mengetahui sampai dimana pelaksanaan tujuan yang sudah ditentukan oleh perusahaan dan mengevaluasi untuk mengetahui berhasil atau tidaknya suatu program dalam sebuah perusahaan.

\section{Tugas Bagian Administrasi}

Tugas dari seorang yang bekerja pada bagian administrasi akan bervariasi antar perusahaan, tetapi terdapat kesamaan kemampuan utama yang dibutuhkan untuk menempati posisi ini. Diantara tugas terpentingnya adalah komunikasi dan organisasi. Kemampuan 
menyampaikan laporan dengan baik dan jelas agar dapat dimengerti, kemampuan mendengar yang baik, kemampuan menulis dengan cepat dan jelas, kemampuan komunikasi yang baik pada saat menerima telepon atau saat ingin telepon, kemampuan mengawasi pekerjaan kantor dan administrasi untuk memastikan kepatuhan terhadap standar kualitas, waktu dan prosedur yang tepat adalah merupakan kemampuan yang sangat penting untuk seorang administrasi, seorang staf administrasi akan berkorespondensi setiap hari dengan orang-orang yang penting. Karena seorang staf administrasi bertanggung jawab dengan hampir semua pekerjaan, kemampuan organisasi yang kuat diperlukan untuk keberhasilan pada posisi ini.

\section{Efektivitas Kerja Administrasi}

Efektivitas adalah salah satu ukuran yang digunakan untuk menunjukan tingkatan keberhasilan dan kegagalan kegiatan manajemen, aktivitas diperlukan oleh organisasi untuk mencapai tujuan organisasi.

Efektivitas menurut Schein (2005) adalah kemampuan untuk bertahan, menyesuaikan diri, memelihara dan tumbuh, lepas dari fungsi tertentu yang dimiliki. Sedangkan menurut Suranto (2005) efektivitas suatu organisasi adalah ukuran yang ditujukkan oleh kenyataan bahwa tujuan organisasi tarsebut dapat dicapai sesuai dengan kebutuhan yang direncanakan. Dari beberapa pengertian diatas, maka dapat disimpulkan bahwa efektivitas kerja adalah kemampuan seseorang dalam melakukan dan menyelesaikan pekerjaannya sesuai dengan tujuan yang telah ditentukan dan menyelesaikan pekerjaannya dalam waktu yang tepat serta tidak melakukan pembuangan tenaga dan biaya agar tujuan yang dicapai dapat maksimal.

Efektivitas kerja dari seorang administrasi dapat ditingkatkan dengan berbagai cara. Menurut Deloittes yang dikutip oleh Tyson dan Jackson (2000), bahwa dalam rangka meningkatkan hasil kerja yang maksimal di perusahaan, maka tingkat efektivitas kerja karyawan pun harus ditingkatkan. Oleh sebab itu, terdapat beberapa hal yang perlu diperhatikan, yaitu:

\section{Waktu}

Waktu dalam menyelesaikan suatu pekerjaan adalah faktor utama, semakin lama tugas yang dibebankan dan dikerjakan, maka semakin banyak pula tugas lain yang akan menyusul dan menumpuk. Hal ini akan memperkecil tingkat efektivitas kerja karena memakan waktu yang tidak sedikit untuk menyelesaikannya. 
2. Tugas

Bawahan harus diberitahu maksud dan tujuan serta seberapa pentingnya tugas yang hendak diberikan padanya sehingga karyawan dapat mengerjakan tugas dengan sebaik-baiknya tanpa rasa ragu.

3. Produktivitas

Apabila seorang karyawan mempunyai produktivitas kerja yang tinggi didalam bekerja tentunya akan dapat menghasilkan efektivitas kerja.

4. Motivasi

Atasan sebaiknya memberikan dorongan kepada bawahan melalui perhatian pada kebutuhan dan tujuan mereka yang sensitif, memotivasi karyawan untuk bekerja secara positif dapat meningkatkan pula kinerja bawahan menjadi lebih baik. Memotivasi karyawan juga dapat dilakukan dengan memberi penghargaan atas hasil yang letah dicapai.

5. Evaluasi Kerja

Manajer memberikan dorongan informasi dan dukungan kepada bawahan. Sebaliknya bawahan harus dapat menerima hasil evaluasi kerja atas setiap pekerjaannya, baik hasil pekerjaan tersebut berupa baik maupun buruk.

6. Pengawasan

Pengawasan sangat perlu dilakukan. Dengan adanya pengawasan maka setiap kinerja karyawan dapat dipantau, sehingga resiko kesalahan dalam melaksanakan pekerjaan dapat diperkecil.

7. Lingkungan Kerja

Lingkungan kerja dipengaruhi oleh kondisi ruang kantor seperti: warna cat ruangan, pencahayaan, tata ruang kantor, suara-suara bising dan gangguan-gangguan lain yang dapat menyebabkan turunnya konsentrasi karyawan dalam bekerja.

8. Perlengkapan dan Fasilitasnya

Perlengkapan adalah sarana yang dapat mendukung setiap kegiatan kantor. Perlengkapan disediakan untuk memberikan kelancaran kepada keryawan dalam melakukan setiap pekerjaannya. Semakin baik sarana yang disediakan oleh kantor, maka semakin baik pula kinerja seseorang karyawan dalam bekerja. 


\section{Kegiatan Administrasi}

Administrasi kantor sebagai suatu kegiatan bersama yang terdapat di setiap perusahaan, selama perusahaan tersebut ingin berhasil dalam mengelola usahanya. Untuk mengetahui hal-hal yang perlu dicatat yang harus ditelusuri adalah semua kegiatan yang dilakukan, kemudian dikelompokan menjadi beberapa jenis kegiatannya. Disamping itu harus ditelusuri pula barang-barang dan hak milik lainnya yang berpengaruh terhadap operasi kegiatan usaha. Bentuk dan model pencatatan bisa bermacam-macam bentuk, tetapi yang perlu diperhatikan adalah bahwa catatan tersebut harus rapi, jelas, sistematik dan mudah untuk dipahami serta mudah untuk dilakukannya pengecekan atau pengawasan.

\section{HASIL DAN PEMBAHASAN}

PT Tangara Mitrakom (Tangara) berdiri pada tahun 1998, difokuskan pada penyedia solusi jaringan, sejalan dengan pemberian lisensi jaringan tetap tertutup yang dikeluarkan oleh pemerintah. Untuk meningkatkan kualitas layanan kepada pelanggan bahwa sebagai operator kelas dunia, Tangara telah berhasil memperoleh ISO 9001: standard 2008 sebagai terakreditasi internasional (United Kingdom Accreditation service-UKAS) sistem manajemen mutu. Ini merupakan realisasi dari komitmen Tangara untuk terus meningkatkan kualitas solusi teknologi informasi untuk kepuasan pelanggan.

Tangara menyediakan layanan telekomunikasi berbasis, packet switched dan penyadia akses jaringan (NAP) izin yang dikeluarkan oleh Menteri Komunikasi dan Informatika. Tangara beroperasi across negara, memberikan solusi komunikasi yang cepat dan dapat diandalkan dengan melayani pelanggan di berbagai segmen, termasuk lebih dari 2.000 area terpencil perbankan diseluruh Indonesia. Sebagai bagian dari inovasi dan pengembangan produk, pada tahun 2010, Tangara adalah perusahaan pertama yang menerapkan Bank Layanan Gerak (BLG), yang mendukung bank untuk bergerak dengan mobil. Ini memberikan teller dan konektivitas ATM menggunakan satelit mobile. Menjaga dengan permintaan yang semakin meningkat untuk kebutuhan suara dan transmisi data, Tangara Mitrakom akan penyedia solusi jaringan preferensi dalam menawarkan serangkaian solusi komunikasi terintegrasi dengan berbagai layanan nilai tambah. 


\section{Komitmen Perusahaan PT Tangara Mitrakom}

Di perusahaan PT Tangara Mitrakom memiliki komitmen yang diantaranya adalah:

1. Menyediakan solusi jaringan internet atau telekomunikasi.

2. Menawarkan solusi biaya produk yang terjangkau dengan kualitas tinggi

3. Memberikan pelayanan dengan teknik professional dan terlatih.

\section{Produk dan Pelayanan PT Tangara Mitrakom}

PT Tangara Mitrakom memproduksi beberapa produk dan jenis pelayanan, diantaranya adalah:

\section{Penyediaan jaringan komunikasi VSAT IP, meliputi :}

a. Penyediaan HUB Station HX System, Antenna Vertex 9.1 meter di Gedung BNI 46

b. Penyediaan HUB Station HX System,Antena vertex 9,3 meter di Buaran

c. Penyediaan perangkat remot

d. Survey dan Instalasi VSAT IP

e. Pengiriman perangkat ke lokasi

f. Pelaksanaan Testing dan Comissioning untuk memastikan kualitas saluran komunikasi

g. Link integration VSAT IP dan data center

h. Operasional and Maintenance 24 jam sehari 7 hari seminggu 365 hari setahun.

i. Dokumentasi \& laporan dari lokasi setiap harinya baik berupa email atau berita acara dari lokasi yang dikirim melalui jasa pengiriman.

2. Penyadiaan Solusi pada Broadband Wireless Access, meliputi:

a. Penyediaan BTS Broadband Wireless Access

b. Penyediaan perangkat CPE ( Customer Premises Equipment)

c. Survey lokasi CPE

d. Pengiriman dan instalasi Perangkat CPE di lokasi pelanggan

e. Pelaksanaan testing dan Comissioning untuk memastikan kualitas saluran komunikasi

f. Link integration Broadband Wireless Access dan data center pelanggan

g. Operasional and Maintenance 24 jam sehari 7 hari seminggu 365 hari setahun. 
h. Dokumentasi \& laporan dari lokasi setiap harinya baik berupa email atau berita acara dari lokasi yang dikirim melalui jasa pengiriman.

3. Penyediaan Solusi ADSL (Asymmetric Digital Subscriber Line) meliputi :

a. Penyediaan Backhaul dari TELKOM ke HUB TM

b. Penyediaan perangkat MODEM Asymmetric Digital Subscriber Line

c. Survey lokasi

d. Pengiriman dan Instalasi Perangkat Asymmetric Digital Subscriber Line di lokasi

e. Pelaksanaan Testing dan Comissioning untuk memastikan kualitas saluran komunikasi

f. Link integration Asymmetric Digital Subscriber Line dan data center pelanggan

g. Operasional and Maintenance 24 jam sehari 7 hari seminggu 365 hari setahun.

h. Dokumentasi \& laporan dari lokasi setiap harinya baik berupa email atau berita acara dari lokasi yang dikirim melalui jasa pengiriman.

\section{Penyediaan Solusi VSAT-IP Internet, meliputi:}

a. Penyediaan Port Internet.

b. Penyediaan perangkat VSAT.

c. Survey lokasi.

d. Pengiriman dan Instalasi VSAT di lokasi.

e. Pelaksanaan uji coba untuk memastikan kwalitas.

f. Operasional dan perbaikan 24 jam sehari, 7 hari seminggu, dalam 356 hari setahun.

g. Dokumentasi dan laporan dari lokasi setiap harinya baik berupa e-mail atau berita acara dari lokasi yang dikirim melalui jasa pengiriman.

\section{Penyediaan Solusi BGAN (Boardband Global Area Network), meliputi:}
a. Penyediaan Airtime
b. Penyediaan perangkat BGAN
c. Pengiriman dan Instalasi perangkat BGAN
d. Pelaksanaan testing dan commissioning untuk memastikakn kualitas
e. Operasional dan perbaikan 24 jam sehari, 7 hari seminggu, dalam 356 hari setahun 
f. Dokumentasi dan laporan dari lokasi setiap harinya baik berupa e-mail atau berita acara dari lokasi yang dikirim melalui jasa pengiriman

\section{Penyediaan Solusi PLTS, Solar Panel, meliputi:}

a. Penyediaan perangkat PLTS.

b. Penyediaan Solar Panel, battery, controller.

c. Pengiriman dan Instalasi perangkat PLTS.

d. Pelaksanaan testing dan commissioning untuk memastikan kualitas

e. Operasional dan perbaikan 24 jam sehari, 7 hari seminggu, dalam 356 hari setahun

f. Dokumentasi dan laporan dari lokasi setiap harinya baik berupa e-mail atau berita acara dari lokasi yang dikirim melalui jasa pengiriman

\section{Penyediaan Solusi BTS Hotel, meliputi:}
a. Site Survey
b. Penyediaan ODAS (Outdoor Distributed Antenna System).
c. Penyediaan IDAS (Indoor Distributed Antenna System).
d. Penyediaan FTTA (Fiber to the Antenna).
e. Penyediaan Pola dan Sarana Pendukung.
f. Operasional dan perbaikan 24 jam sehari, 7 hari seminggu, dalam 356 hari setahun.
g. Dokumentasi dan laporan dari lokasi setiap harinya baik berupa e-mail atau berita acara dari lokasi yang dikirim melalui jasa pengiriman.

\section{Penyediaan Solusi Data Center, meliputi:}
a. Kunjungan lokasi.
b. Penyediaan Rack di lokasi.
c. Penyediaan Bandwidth Internet.
d. Penyediaan Server dan Sarana Pendukung.
e. Operasional dan perbaikan 24 jam sehari, 7 hari seminggu, dalam 356 hari setahun.
f. Dokumentasi dan laporan dari lokasi setiap harinya baik berupa e-mail atau berita acara dari lokasi yang dikirim melalui jasa pengiriman.


9. Implementasi dan Design GSM/CDMA untuk Area Indoor (Active/Passive), meliputi:
a. Site Survey
b. Site Acquisition
c. Coverage Design
d. Instalasi of Feeder \& Accessories
e. Instalasi Civil, Mechanical \& Electrical
f. Test and Commissioning

10. Optimization GSM/CDMA untuk area Indoor (Active/Pasive), meliputi:
a. Site Audit.
b. Feeder \& Accessories Replacement.
c. VSWR Test.
d. Drive Test.

11. Implementasi dan Design GSM/CDMA Area Outdoor (Active/Pasive), meliputi:
a. LOS Survevy.
b. Instalasi of RBS.
c. Instalasi of Minilink/Transmission.
d. Instalasi of Power System.
e. Test and Commisioning Minilink, RBS dan Power System.

12. Optimization GSM/CDMA Area Outdoor (Active/Pasive), meliputi:
a. Site Survey/Audit.
b. Feeder Replacement.
c. VSWR Test.

13. Instalasi dan Implementasi BSC \& MSC, meliputi:
a. Site Survey.
b. Instalasi of BSC \& MSC.
c. Instalasi of Power System.

\section{Peranan Bagian Administrasi Kantor di PT Tangara Mitrakom}

Kegiatan Bagian Administrasi kantor di PT Tangara Mitrakom bertujuan untuk menyelesaikan segala pekerjaan kantor guna mencapai tujuan yang telah ditetapkan oleh 
perusahaan. Peranan Bagian administrasi kantor sangat diperlukan, karena membantu memberikan data dan informasi yang jelas dan benar yang diperlukan oleh pimpinan untuk mempermudah seorang pimpinan dalam mengambil keputusan dalam menyelesaikan suatu masalah yang ada. Administrasi kantor juga berperan penting dalam memudahkan atau meringankan tugas setiap karyawan yang melaksanakan tugas kantor, dan administrasi kantor juga membantu kelancaran perkembangan kantor untuk tujuan yang sudah ditetapkan perusahaan sehingga hasil yang didapatkan memberikan kepuasan untuk karyawan, pimpinan serta perusahaan.

Adapun peranan Bagian Administrasi kantor PT Tangara Mitrakom adalah:

1. Membantu kelancaran dalam pekerjaan kantor, meliputi:

a. Penyimpanan dokumen kantor dengan lebih rapi (filling)

b. Mengaatur kegaitan perusahaan agar dapat berjalan sesuai dengan jadwal

c. Mengelola database yang secara rutin diperbaharui untuk kemajuan perusahaan,

2. Membantu mencatat dan mendokumentasi semua kegiatan-kegiatan atau aktivitas yang terjadi di perusahaan.

3. Membantu menyusun program kegiatan atau aktivitas yang akan diadakan oleh perusahaan baik di lingkungan kantor maupun diluar lingkungan kantor.

Jadi secara umum kegiatan peran Bagian administrasi PT Tangara Mitrakom adalah mencatat, memeriksa, mengarsipkan dokumen atau surat-surat sampai dengan memusnahkannya apabila sudah lebih dari batas waktu yang telah ditentukan perusahaan.

\section{Hambatan Bagian Administrasi Kantor di PT Tangara Mitrakom}

Dalam melaksanakan fungsi dan peranannya staf administrasi kantor sering mengalami hambatan dalam pekerjaannya seperti:

1. Sering terjadinya keterlambatan pada saat pengiriman dan penerimaan laporan administrasi baik melalui $e$-mail ataupun via pos atau pengiriman kilat yang berupa dokumen.

2. Sering terjadinya kesalahpahaman saat komunikasi baik secara langsung maupun lewat telepon atau dokumen surat. 
3. Sering terjadinya perbedaan pencatatan laporan administrasi (kelebihan atau kekurangan dalam pencatatan laporan).

Adapun cara-cara untuk mengatasi hambatan-hambatan yang terjadi di perusahaan yaitu:

1. Adanya pengecekan setiap minggu di jaringan internet di perusahaan, agar apabila ada masalah bisa segera diperbaiki sehingga bisa selalu menjaga kondisi baiknya jaringan internet di perusahaan.

2. Baiknya dalam komunikasi diperhatikan cara penyampaian kalimat, pengetikan kata-kata atau huruf-huruf, bahas yang digunakan yang mudah dimengerti sehingga mempermudah orang untuk menerimanya.

3. Selalu diadakan audit disetiap bulannya agar memperkecil masalah perbedaan pencatatan laporan administrasi.

\section{Manfaat Bagian Administrasi Kantor di PT Tangara Mitrakom}

Dengan adanya staf administrasi kantor pekerjaan akan lebih rapi dan teratur sesuai dengan tugas yang diperintahkan, sistem pencatatan dan dokumentasi tersimpan dengan baik dan apabila dibutuhkan akan mudah untuk dicari, perusahaan juga dapat dengan mudah mengikuti segala perkembangan perusahaan melalui laporan hasil pencatatan dan dokumentasi yang dicatat oleh staf administrasi.

\section{PENUTUP}

\section{Kesimpulan}

Berdasarkan uraian dan pembahasan yang telah penulis sampaikan di atas, maka penulis dapat memberikan beberapa kesimpulan, diantaranya adalah:

1. PT Tangara Mitrakom bergerak di bidang solusi jaringan atau telekomunikasi vsat-ip yang mempunyai visi, misi perusahaan yang belum berjalan dengan baik dikarenakan:

a. Sering terjadinya keterlambatan pada saat pengiriman dan penerimaan laporan administrasi baik melalui email ataupun kirim via pos atau pengiriman kilat yang berupa dokumen.

b. Sering terjadinya kesalahpahaman saat komunikasi baik secara langsung maupun lewat telepon atau dokumen surat. 
c. Sering terjadinya perbedaan pencatatan laporan administrasi (kelebihan atau kekurangan dalam pencatatan laporan).

2. Peranan staf administrasi kantor PT Tangara Mitrakom belum berjalan dengan baik dan lancar dikarenakan kurangnya karyawan untuk bagian administrasi.

3. Kinerja administrasi kantor PT Tangara Mitrakom belum berjalan maksimal dikarenakan kurangnya fasilitas dan perlengkapan kantor yang dibutuhkan yang mempengaruhi kegiatan dan kelancaran karyawan dalam bekerja, misalnya: mesin fotocopy dan printer, jaringan internet untuk mengakses email, pesawat telepon yang sering gangguan tidak dapat melakukan panggilan keluar kantor).

\section{Saran-Saran}

Berdasarkan kesimpulan diatas penulis dapat memberikan saran sebagai berikut :

1. Terjadinya keterlambatan pada saat pengiriman dan penerimaan laporan administrasi

Solusinya adalah adanya pengecekan setiap minggu di jaringan internet di perusahaan, agar apabila ada masalah bisa segera diperbaiki sehingga bisa selalu menjaga kondisi baiknya jaringan internet di perusahaan.

\section{Terjadinya kesalahpahaman saat komunikasi}

Solusinya adalah dalam komunikasi diperhatikan cara penyampaian kalimat, pengetikan kata-kata atau huruf-huruf, bahasa yang digunakan yang mudah dimengerti sehingga mempermudah orang untuk menerimanya.

\section{Terjadinya perbedaan pencatatan laporan administrasi}

Solusinya adalah selalu diadakan audit disetiap bulannya agar memperkecil masalah meperbedaan pencatatan laporan administrasi di perusahaan.

\section{Kurangnya karyawan untuk bagian administrasi}

Solusinya adalah perlu ditambahnya karyawan agar pekerjaan administrasi bisa berjalan lancar dan baik.

\section{Kurangnya fasilitas dan perlengkapan kantor yang dibutuhkan}

Solusinya adalah dilengkapi segera fasilitas dan perlengkapan kantor yang dibutuhkan agar mempercepat proses kegiatan dalam bekerja dan dapat menghemat waktu. Semakin baik 
sarana yang disediakan oleh perusahaan akan mempengaruhi hasil kerja karyawan yang tentunya akan mencapai tujuan yang diharapkan oleh perusahaan.

6. Untuk yang berada di daerah perlu diadakannya training di kantor pusat agar setiap masalah yang ada dapat dilaporkan dan dibuatkan berita acara laporannya, sehingga perusahaan memiliki kesinambungan dalam pelaporan administrasi.

\section{DAFTAR PUSTAKA}

Gie, The Liang, “Administrasi Perkantoran Modern”, Penerbit Gunung Agung, Jakarta, 2000.

Gie, The Liang, “Kamus Administrasi Perkantoran”, Penerbit Gunung Agung Yogyakarta, 2003.

Poerwanto, “New Business Administration", Penerbit Pustaka Pelajar, Yogyakarta, 2006.

Sastradipoera, Komaruddin, "Manajemen Kantor Teori dan Praktek", Penerbit Triyenda Karya, Bandung, 1993.

Sastradipoera, Komaruddin, "Asas-asas Manajemen Perkantoran Suatu Pendekatan Sistem Informasi Manajemen”, Penerbit Kopra Sigma, Bandung, 2000.

Sedarmayanti, "Tugas dan pengembangan Administrasi”, Penerbit mandar maju, Semarang, 2005.

Siagaan, Sondang, P, Prof., Dr., M.P.A.,"Administrasi Pembangunan”, Penerbit CV Haji Masagung, Jakarta, 2006.

Silalahi, Ulbert, Drs., M.A., "Studi Tentang Ilmu Administrasi”. Penerbit Sinar Baru, Bandung, 2005.

Tedjasutisna, Ating, “Administrasi Kantor”, Penerbit Armico, Bandung, 2003

Waworuntu, Tony, “Manajemen Untuk Sekertaris", Penerbit PT Gramedia Pustaka Utama, Jakarta, 1995 